\title{
MINERALOGY OF THE POLLUTANT PRODUCTS FORMED IN THE MAŞCA EXPLORATION AREA (LOWER IARA VALLEY BASIN, CLUJ COUNTY, ROMANIA)
}

\author{
LUCREȚIA GHERGARI $^{1} \&$ JUDIT GÁL ${ }^{1}$
}

\begin{abstract}
In the present study the mineralogy of a tailing dam situated in the Maşca mining area is discussed. Our aim was to point out the physicochemical processes, which occur under the action of the exogenous factors. The studied samples were collected from different levels of the dam wall, from the Maşca mine and lara river waters. The applied analytical methods are: transmission polarized microscopy, transmission electron microscopy, X-ray diffractometry, and atomic absorption spectrometry. The physicochemical parameters have been measured in situ and in the laboratory.

The minerals present in the tailings are represented by: garnets (andraditegrossular and almandine series), diopside, hedenbergite, actinolite, tremolite, epidote, zoisite, biotite, phlogopite, serpentine minerals, chlorite, tourmaline, quartz, feldspar, anatase, apatite and opaque minerals (pyrrhotite, pyrite, magnetite and hematite). The carbonate minerals belonging to the mining waste are represented mostly by dolomite and subordinately by calcite. The identified neoformation minerals formed as a result of the action of the exogenous factors are the following: illite, illite/smectite, nontronite, palygorskite, chlorite-vermiculite, gypsum, epsomite, hexahydrite, wattevillite, ferrohexahydrite, hallotrichite, bilinite(?), goethite and amorphous iron hydroxide.

The chemical analyses undertaken on the water samples show high values of the soluble salts $\left(\mathrm{Na}^{+}, \mathrm{K}^{+}, \mathrm{Ca}^{2+}, \mathrm{Mg}^{2+}\right.$, and $\left.\mathrm{SO}_{4}{ }^{2-}\right)$ and heavy metals $\left(\mathrm{Cu}^{2+}, \mathrm{Pb}^{+}, \mathrm{Fe}^{2+}\right.$, $\mathrm{Fe}^{3+}$, and $\mathrm{Zn}^{2+}$ ) contents, exceeding international and national guidelines. Although the $\mathrm{pH}$ of the streams originating from the mine area vary between neutral to slightly alkaline, pollution occurs and significantly impacts the mineralized area as well as the neighboring areas.
\end{abstract}

Keywords: Tailing dam mineralogy, heavy metal mobility, Maşca, Romania.

\section{INTRODUCTION}

This paper presents a detailed study on the mineralogy of the tailings dam from the Maşca mining area (Cluj County, Romania). The aim of the study is to emphasize the physicochemical processes, which under the action of the exogenous factors contribute to the weathering of the solid mining wastes. Secondary minerals, formed due to the alteration of various sulfides, playing an important role in the mobilization of the pollutant heavy metals, were also investigated.

\section{STUDY AREA}

The examined area is situated in the eastern part of the Gilău Massif, at its morphostructural contact with the lara basin. Samples were collected from the tailings dam (from different levels of the wall), and its neighborhood, stream waters (treated and untreated), as well as from the lara valley (Fig. 1).

\footnotetext{
1 "Babeş-Bolyai" University, Department of Mineralogy, Kogălniceanu 1, 400084 Cluj-Napoca, Romania.
} 


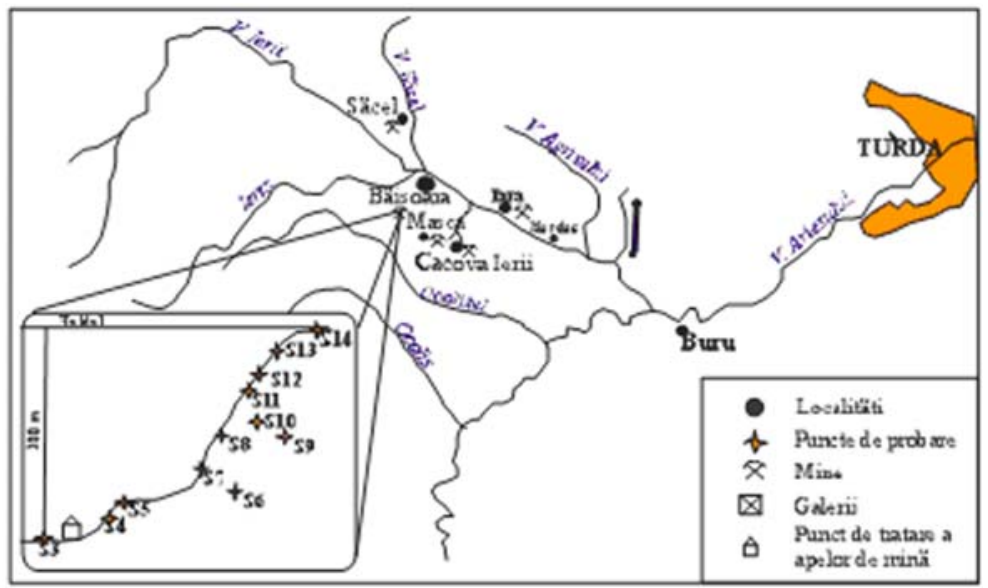

Fig. 1. Map of the studied area and sampling locations.

The geological background of this area consists of metamorphic formations, structurally represented by the Bihor unit, and Gârda, Biharia and Baia de Arieş nappes (Balintoni, 1997), Permian, Cretaceous, Paleogene, Neogene and Quaternary sedimentary formations as well as igneous formations (Muntele Mare granitic massif, Jurassic island arc magmatism and laramic magmatism). The emplacement of the laramic magmatites has been accompanied by a variety of thermal and metasomatic metamorphic processes, as well as by an intensive metallogenetic activity (Cioflica et al., 1973, 1984; Borcoş et. al., 1984; Ştefan et al., 1988). In the Maşca mining area the mineralization is accumulated in pyrometasomatic bodies, consisting of garnet and pyroxene skarns (Lazăr et al., 1971, 1972, 1979; Gheorghițescu et al., 1979).

The postmagmatic processes associated with the laramic intrusions from the Maşca-Băişoara area led to the formation of oxide minerals (magnetite, hematite) and subordinately sulfides (pyrrhotite and in smaller amounts pyrite, sphalerite, galena, chalcopyrite). The pyrometasomatic accumulations of magnetite represent the economical interest in this area.

Due to the prevailing occurrence of the iron oxides (magnetite, hematite) and pyrrhotite within the Băişoara ore (Maşca sector), it can be concluded that the geochemistry of the mineralization process was dominated by the presence of three essential elements: iron, oxygen and sulfur (Întorsureanu, 1975).

\section{ANALYTICAL METHODS}

Analyses have been carried out by using the following analytical methods: transmission polarized microscopy (Jenapol), transmission electron microscopy, TEM (Tesla B650), X-ray diffractometry (Dron $3-\mathrm{Cu}$ anticathode, Ni filter, $2 \theta=4-64^{\circ}$; Philips PW1710 - Cu anticathode, $2 \theta=3-85^{\circ}$ ) and atomic absorption spectroscopy ${ }^{2}$. The physicochemical properties: $\mathrm{pH}$, Eh, electrical conductivity (EC), and total dissolved salts (TDS) content of the collected soil and water samples have been measured in situ and in the laboratory, by using the potentiometric method with

${ }^{2}$ Analyses undertaken in the Laboratory of the Environmental Protection Agency, Baia Mare. 54 
EMIS-Cu ion-sensitive electrode and a reference RBD (Ag-AgCl type) electrode. Quantitative determinations have been based on microscopy data corroborated with the values obtained from the intensities of the X-ray diffraction lines (method of the proportional constants).

\section{RESULTS AND DISCUSSIONS}

In the case of the Maşca mining area, the magnetite mineralization (the object of the mining activity) is accumulated in bodies associated with garnet and/or pyroxene skarns. The tailing dam contains important quantities of skarn minerals represented by silicates (garnets, pyroxenes, amphiboles, etc.), carbonates (dolomite and subordinately calcite) and metallic minerals (sulfides and oxides). All the mentioned minerals are subject to the oxidation-hydration processes, leading to the formation of various compounds, which contribute to the pollution of the environment (soils and waters).

The tailings dam is composed of minerals refractory to the attack of the exogenous factors as well as of products formed due to the reaction of the carbonates and subordinately silicates with the aggressive compounds resulting from the oxidation of the sulfides. The minerals occurring in the tailings are represented by: garnets (andradite-grossular series and subordinately almandine), diopside, hedenbergite, actinolite, tremolite, epidote, zoisite, biotite (sometimes Fe-depleted to various extent), phlogopite, talc, serpentine minerals, chlorite, tourmaline, quartz, feldspars, anatase, apatite, magnetite and hematite.

The most aggressive pollutant compounds form by the alteration of sulfides, especially of pyrite.

The identified neoformation minerals are: illite, illite/smectite, nontronite, palygorskite, chlorite-vermiculite, gypsum, epsomite, hexahydrite, wattevillite, ferrohexahydrite, hallotrichite, bilinite (?), goethite and amorphous iron hydroxide (Table 1).

Mineralogical composition of minerals from the tailings

Table 1 dam and their alteration products

\begin{tabular}{|c|c|c|}
\hline \multicolumn{2}{|c|}{ Primary minerals } & Secondary minerals \\
\hline Origin & Mineral associations & \\
\hline 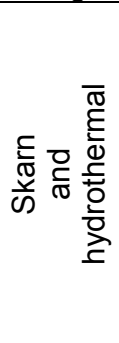 & $\begin{array}{l}\text { Pyroxenes } \\
\text { Amphiboles } \\
\text { Garnets } \\
\text { Micas } \\
\text { Chlorite } \\
\text { Epidote } \\
\text { Zoisite } \\
\text { Palygorskite } \\
\text { Talcum } \\
\text { Barite }\end{array}$ & $\begin{array}{c}\text { Gypsum } \\
\text { Goethite } \\
\text { Wattevillite } \\
\text { Epsomite } \\
\text { Hexahydrite } \\
\text { Ferrohexahydrite } \\
\text { Hallotrichite } \\
\text { Bilinite(?) } \\
\text { Illite } \\
\text { Illite/smectite }\end{array}$ \\
\hline 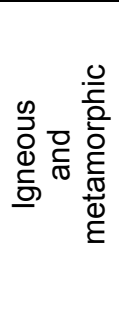 & $\begin{array}{l}\text { Feldspars } \\
\text { Quartz } \\
\text { Hornblende } \\
\text { Zircon } \\
\text { Muscovite } \\
\text { Biotite } \\
\text { Chlorite } \\
\text { Tourmaline } \\
\text { Apatite }\end{array}$ & $\begin{array}{l}\text { Montmorillonite } \\
\text { Kaolinite } \\
\text { Nontronite }\end{array}$ \\
\hline
\end{tabular}




\section{MINERALOGY OF THE TAILINGS DAM}

Samples collected from all the benches along the slope of the tailings dam - from the wall surface as well as from about $1 \mathrm{~m}$ inward - have been used for the mineralogical investigation. The mineral composition has been determined on bulk samples (Table 2$)$ and on the fine particles fraction $(<10 \mu \mathrm{m})$ mainly consisting of reaction products. Identification and quantitative evaluation was based on polarized microscopy study on thin/pulverized sections, XRD analyses on bulk samples and on unoriented and oriented samples prepared from the fine fraction. The $<2 \mu \mathrm{m}$ mineral fractions were studied using TEM. The most characteristic XRD spectra are presented in Fig. 2.

Table 2

Bulk mineralogical composition.

\begin{tabular}{|c|c|c|c|c|c|c|c|c|c|c|c|c|c|}
\hline \multirow{2}{*}{$\begin{array}{l}\frac{0}{7} \\
\frac{0}{0}\end{array}$} & \multirow[t]{2}{*}{ Mineral } & \multicolumn{12}{|c|}{$\begin{array}{l}\text { Semi-quantitative mineral composition in the bulk samples } \\
(\%)\end{array}$} \\
\hline & & 3 & 4 & 5 & 6 & 7 & 8 & 9 & 10 & 11 & 12 & 13 & 14 \\
\hline \multirow[b]{3}{*}{1} & Quartz & 11 & 5 & 9 & 10 & 38 & 6 & 49 & 12 & 2 & 6 & 3 & 3 \\
\hline & Feldspars & 4 & - & 7 & 8 & 13 & 5 & 27 & 1 & 6 & 5 & 3 & 4 \\
\hline & Micas-illite & 7 & 11 & - & - & 20 & 6 & 5 & 3 & 6 & 4 & 2 & 8 \\
\hline \multirow{7}{*}{2} & Garnets & 3 & 2 & 4 & - & - & 5 & - & - & 5 & 20 & 8 & 4 \\
\hline & Pyroxenes & 1 & 1 & - & - & - & 4 & - & - & 2 & 2 & 4 & 4 \\
\hline & Amphiboles & 6 & 2 & 2 & - & 3 & 4 & - & - & 6 & 6 & 3 & 6 \\
\hline & Epidote & 2 & - & 1 & - & - & 1 & - & - & - & 1 & 3 & 2 \\
\hline & Talc & 8 & - & 4 & - & - & 7 & - & - & 5 & 5 & 8 & 8 \\
\hline & Chlorite & 12 & - & 5 & - & 6 & 11 & - & - & 9 & 9 & 9 & 14 \\
\hline & Opaque minerals & & & & & & & & & & 1 & 1 & 1 \\
\hline \multirow[t]{2}{*}{3} & Dolomite & 15 & 23 & 46 & 15 & - & 19 & 6 & 28 & 37 & 20 & 34 & 30 \\
\hline & Calcite & 14 & 9 & 10 & 15 & - & 23 & 1 & 35 & 16 & 16 & 16 & 12 \\
\hline \multirow{8}{*}{4} & Kaolinite & & & & & 10 & & & & & & & \\
\hline & Gypsum & 5 & 3 & 4 & 36 & 5 & 5 & 5 & 20 & 4 & 4 & 5 & 2 \\
\hline & Hexahydrite & 1.5 & & 1 & 1 & & & & & & & & \\
\hline & Ferrohexahydrite & 0.5 & & & & & & & & & & & \\
\hline & Epsomite & & 2 & 3 & 1 & & & & & & & & 2 \\
\hline & Wattevillite & & 1 & & & & & & & & & & \\
\hline & Goethite & & & 4 & 14 & 5 & 4 & 7 & 1 & 2 & 1 & 1 & \\
\hline & $\begin{array}{l}\text { Amorphous } \\
\mathrm{Fe}(\mathrm{OH})_{3}\end{array}$ & 10 & 41 & & & & & & & & & & \\
\hline
\end{tabular}

The mineral composition of the collected samples varies depending on the location of the sampling point. Accordingly, three different zones can be distinguished: the basal part of the dam's wall, including the adjacent zone (samples S3-5) with the most significant mineralogical transformations; the upper zone of the tailings dam (samples S11-14, the last one originating from the surface of the tailings pond) where the transformations are at a smaller scale; finally, the median part of the dam (samples S7-9) with a wide variation of the mineral composition depending on the local characteristics of the tailings and the oxidation degree (Table 2). Samples S6 and S10 were collected from the surface of the wall, where efflorescences were noticed. 


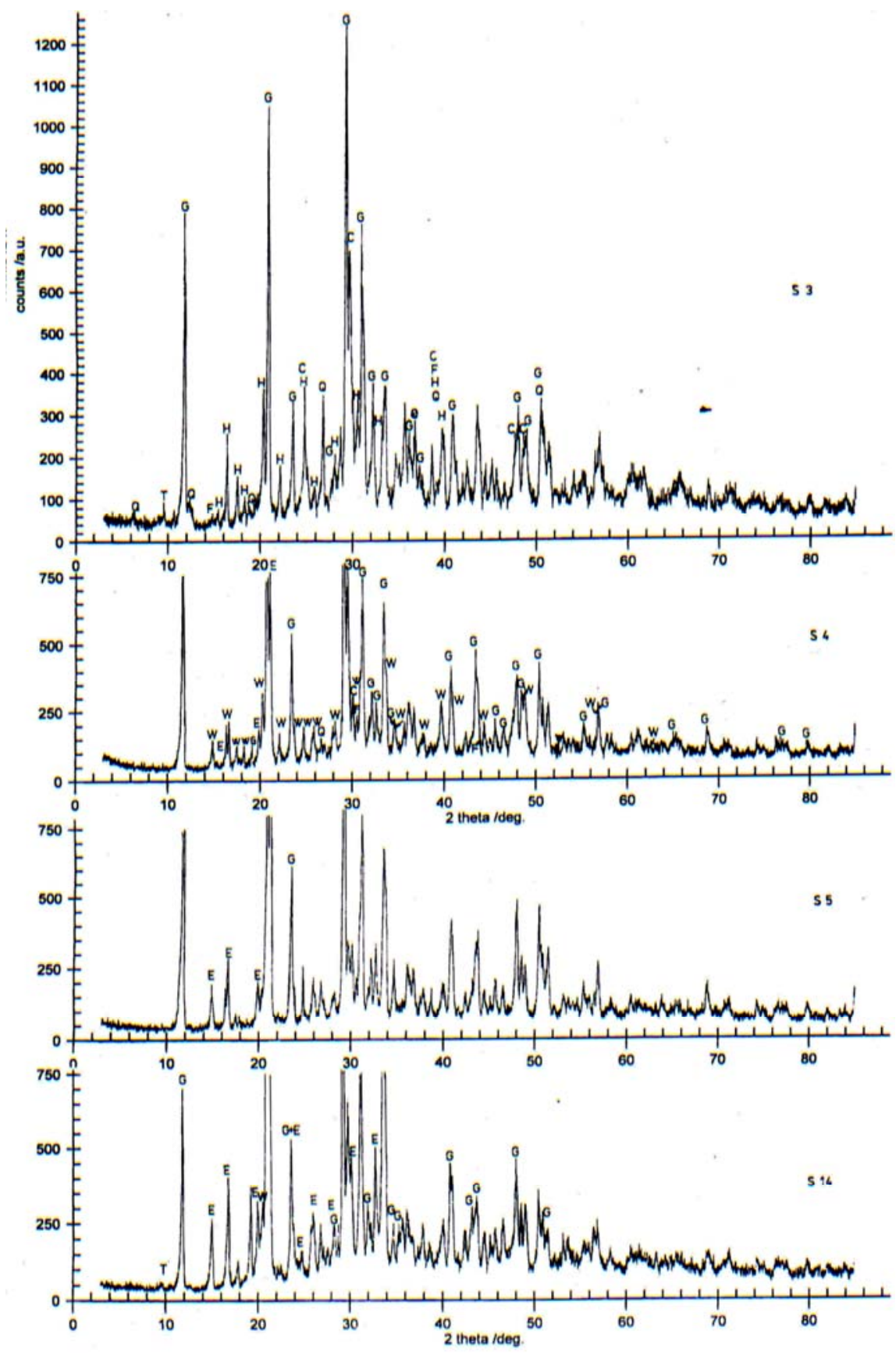

Fig. 2. X-ray diffraction spectra of the fine fraction (samples S3, S4, S5, and S14). $Q$ - quartz; G-gypsum; F-ferrohexahydrite, $H$ - hexahydrite; $C$ - calcite; W-watevillite; $\mathrm{E}$ - epsomite; $\mathrm{T}$ - talc; $\mathrm{Cl}$ - chlorite. 
For a better differentiation of the wastes' mineral composition, as well as its degree of weathering under the action of the exogenous factors, we distinguished the following mineralogical classes:

- common silicate minerals of igneous and metamorphic nature (quartz, feldspars, micas and illite);

- minerals resulted from the skarn-generation and mineralization processes;

- buffer minerals (dolomite and calcite);

- neoformation minerals resulted from exogenous weathering.

In the upper zone of the tailings dam's wall (samples S11-14) the mineral composition is relatively similar and it can be characterized by a high carbonate content (dolomite and calcite 36-53\%), low amounts of reaction products (gypsum, epsomite and goethite $4-6 \%)$, skarn minerals $(27-44 \%)$, the rest $(8-15 \%)$ being represented by quartz, feldspars, micas and illite varieties.

Significant variations can be noticed in the composition of the samples collected from the median to the basal zone of the dam's wall. Depending on the location of the sampling site (at the surface of the wall: samples S6 and S10, or at about $1 \mathrm{~m}$ inwards: samples S7-9) the mineral composition is different. Thus, all the deep samples contain reduced amounts of reaction products but their mineral composition is variable: sample S8 is similar to the samples collected from the upper zone of the dam's wall (buffer minerals $42 \%$, neoformation minerals $9 \%$, compounds resulting from the mineralization process $32 \%$ and minerals belonging to the first class 17\%); the other two samples (samples S7 and S9) do not belong to the skarn zone, they consist of silicates of igneous and/or metamorphic origin ( 71 and $81 \%$, respectively); the buffer minerals are either missing or they are present only in reduced quantities. Samples taken from the surface of the wall (samples S6 and S10) consist of silicate minerals (18 and $16 \%$, respectively), buffer minerals (30 and $63 \%$, respectively) and reaction products (52 and $21 \%$, respectively).

Samples collected from the outer part of the wall (at its base) have different mineralogical composition depending on the place from where they have been collected: upstream the treatment plant (sample S5) or downstream (samples S3 and S4).

Sample S5 is predominantly constituted of buffer minerals (56\%) and in smaller quantities by micas and feldspars (16\%), skarn minerals $(16 \%)$ and reaction products $(12 \%)$. The composition of the material accumulated downstream the treatment plant/station is represented by reaction products (17 and $47 \%$, respectively), buffer minerals (29 and $32 \%$, respectively) and to a lesser extent skarn minerals ( 32 and $5 \%$, respectively), as well as silicate minerals from the first group (22 and $16 \%$, respectively).

The fine (particle size) fraction $(<10 \mu \mathrm{m})$ of the analyzed samples is constituted of silicate minerals (clay minerals in majority), iron oxy-hydroxides and sulfates. The ratio between the minerals from the three groups varies depending the on the location of the sampling site. Thus, the silicate minerals are dominant in the samples originating from the wall of the tailings dam, while the sulfates and iron oxy-hydroxides are predominantly present in the samples taken from the base of the wall (S3-5) and from the top of the dam (surface of the pond) (S14, Fig. 3 a, b). 

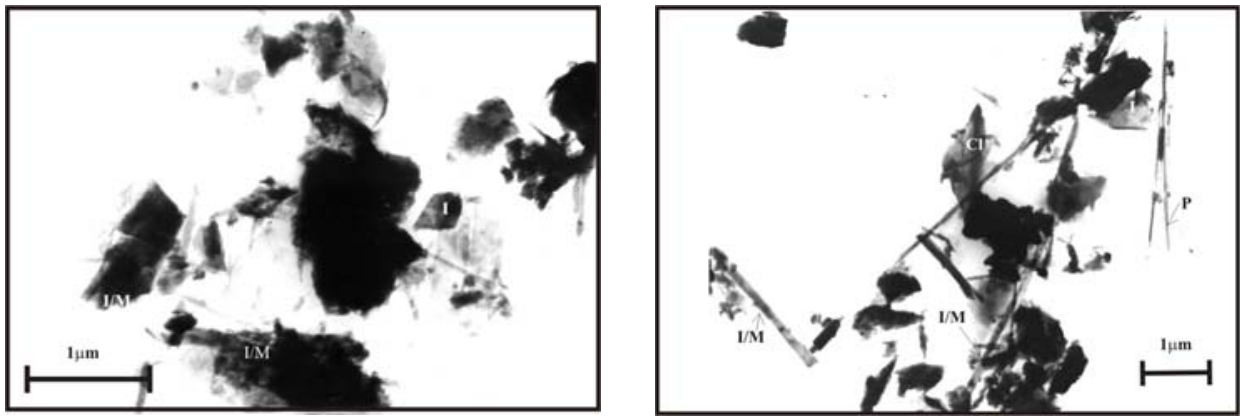

Fig. 3 a. Illite/montmorilonite (I/M), illite (I), goethite. Sample S14 TEM - Clay particles $<2 \mu m$.

b. Chlorite (CI), palygorskite (P), illite (I), Illite/montmorilonite (I/M), goethite. Sample S14 TEM - clay particles $<2 \mu m$.

The silicate minerals consist of the following association: chlorite, talc, illite, nontronite, palygorskite, kaolinite and illite/smectite interstratifications. These minerals have been also identified in the TEM images ( $<2 \mu \mathrm{m}$ fraction) together with goethite, amorphous iron hydroxide, carbonates and sulfates (Fig. 4 a, b).

The fine fraction constituted of sulfate minerals mainly contains gypsum (45-57\%), epsomite (25-41\%), hexahydrite (16 and 6\%, respectively), ferro-hexahydrite $(6 \%)$, wattevillite (10\%), and subordinately hallotrichite (S14) and bilinite(?) (S3), whereas the group of non-sulfate minerals $(5-26 \%)$ is represented by quartz, calcite, talc, chlorite-vermiculite and smectite.
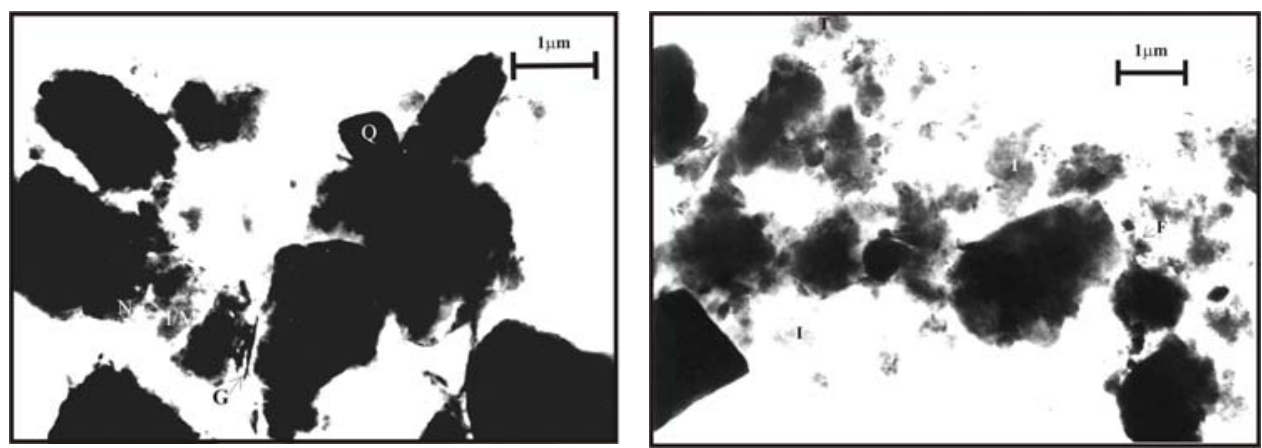

Fig. 4 a. Illite/smectite (I/M), goethite (G), nontronite (N), quartz (Q). Sample S7 TEM - clay

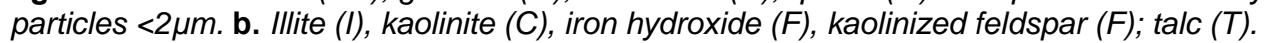
Sample S7 TEM - clay particles $<2 \mu \mathrm{m}$.

\section{ASSESSMENT OF THE ENVIRONMENTAL ASPECTS}

For a better understanding on the redox conditions and the $\mathrm{pH}$ of the environment where transformation processes have been undergoing, the following measurements have been undertaken: $\mathrm{pH}$, Eh [mV], EC [ $\mu \mathrm{S}]$ and TDS (Table 3). Distilled water was added to the soil samples (S3-S14); after filtering, measurements were taken by introducing the suitable electrode in the solution and in the collected water samples (A11-A14). 
Table 3

Physicochemical parameters of the collected solid (S) and water samples (A).

\begin{tabular}{|c|c|c|c|c|}
\hline Sample number & pH & Eh [mV] & EC $[\mu$ S] & TDS \\
\hline S3 & 7.6 & 56 & 838 & 600 \\
\hline S4 & 7.6 & 238 & 942 & 677 \\
\hline S5 & 7.2 & -22 & 702 & 500 \\
\hline S7 & 6.9 & 239 & 604 & 427. \\
\hline S9 & 7.5 & 215 & 618 & 438 \\
\hline S11 & 7.4 & 225 & 928 & 666 \\
\hline S12 & 7.6 & 300 & 772 & 551 \\
\hline S13 & 7.5 & 229 & 668 & 475 \\
\hline S14 & 7.5 & 213 & 701 & 499 \\
\hline A12 pond effluent, corresponding to S4 & 7.7 & 81 & 723 & 515 \\
\hline $\begin{array}{c}\text { A13 effluent located at the confluence } \\
\text { with lara Valley }\end{array}$ & 6.8 & 173 & 1533 & 1113 \\
\hline $\begin{array}{c}\text { A14 lara Valley, 50 m downstream } \\
\text { from the confluence }\end{array}$ & 6.8 & 170 & 1557 & 1131 \\
\hline & & 183 & 229 & 151 \\
\hline
\end{tabular}

The reaction products are mostly represented by sulfates and iron hydroxides, which are more abundant at the base of the tailings dam's wall, in the confluence zone. They represent the evidence of the oxidation-hydration of sulfides, especially of pyrite. Nevertheless, oxidation-hydration does not prevent the environment to become slightly alkaline due to the significantly high occurrence of carbonate minerals (dolomite-calcite). The redox conditions vary from slightly negative Eh to $+0.3 \mathrm{~V}$ values, which fitted in the $\mathrm{Fe}-\mathrm{C}-\mathrm{O}-\mathrm{H}$ system define a narrow domain, overlapping the $\mathrm{Fe}(\mathrm{OH})_{3}$ and slightly the $\mathrm{Fe}^{2+}$ fields. The electric conductivity (EC) varies between 604 (corresponding to the sample with no skarn mineralization) and 942 (at the exit from the treatment plant/station). The total dissolved salts contents, calculated from the conductivity values show elevated levels.

The streams originating from the tailings dam have a nearly neutral character $(\mathrm{pH}: 6.8-7.2)$, due to the fact that the acidic products resulting from sulfides' oxidation are neutralized by the high quantity of carbonates present in the tailings (Table 3). The redox potential (Eh) data, obtained from the water samples show values between 50 and $183 \mathrm{mV}$, i.e. stability conditions corresponding to the $\mathrm{Fe}(\mathrm{OH})_{3}$ field.

\section{CHEMISTRY OF THE WATER SAMPLES}

The highest salt content $\left(\mathrm{Na}^{+}, \mathrm{K}^{+}, \mathrm{Ca}^{2+}, \mathrm{Mg}^{2+}\right.$ and $\left.\mathrm{SO}_{4}{ }^{2-}\right)$ in the water samples was recorded at the highest $\mathrm{pH}$ value (7.2) in the sample collected from the effluents originating from the tailings pond (Table 4). On the contrary, the heavy metals: $\mathrm{Cu}^{2+}, \mathrm{Pb}^{+}, \mathrm{Fe}^{2+}, \mathrm{Fe}^{3+}$ and $\mathrm{Zn}^{2+}$, show higher concentration levels at the lowest $\mathrm{pH}$ values. 
Ion concentrations in the water samples $(\mathrm{mg} / \mathrm{l})$.

\begin{tabular}{|c|c|c|c|c|c|c|c|c|c|c|c|}
\hline $\begin{array}{l}\dot{0} \\
\frac{0}{0} \\
\frac{0}{0} \\
\frac{0}{\pi} \\
\text { ஸे }\end{array}$ & 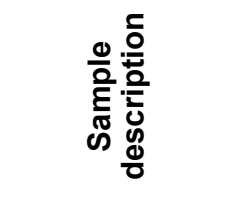 & $\stackrel{+}{\mathbb{N}}$ & $\stackrel{+}{\infty}$ & ¿̇ं & צ & $+\frac{+\pi}{z}$ & $\stackrel{+}{\Xi}$ & 离 & $\stackrel{+}{+}$ & $\stackrel{+}{N}_{N}^{N}$ & $\stackrel{+}{\stackrel{+}{0}}$ \\
\hline$\frac{\Sigma}{\varepsilon}$ & 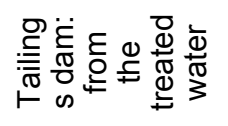 & $\stackrel{\widetilde{m}}{\leftarrow}$ & à & $\begin{array}{l}\mathscr{P} \\
\stackrel{్}{\circ}\end{array}$ & $\underset{\nabla}{ }$ & $\underset{\mathcal{F}}{\sim}$ & סु & $\begin{array}{l}1 \\
\infty \\
0 \\
0 \\
0\end{array}$ & $\begin{array}{l}0 \\
\stackrel{8}{\circ} \\
0\end{array}$ & $\begin{array}{l}\text { ָे } \\
\text { ○़ } \\
0\end{array}$ & $\begin{array}{l}0 \\
\varnothing \\
\end{array}$ \\
\hline$\stackrel{N}{<}$ & 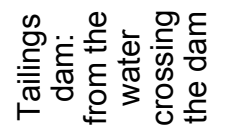 & 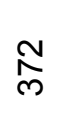 & ల్ల & ণ্ & $\stackrel{2}{\sim}$ & 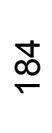 & 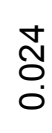 & $\frac{\text { o }}{0}$ & $\stackrel{\stackrel{m}{ }}{\circ}$ & $\begin{array}{l}\widetilde{o} \\
\text { ○े }\end{array}$ & $\begin{array}{l}\infty \\
\stackrel{0}{0} \\
0\end{array}$ \\
\hline$\frac{m}{<}$ & 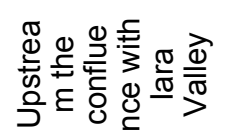 & $\underset{f}{\check{Y}}$ & $\stackrel{\infty}{-}$ & $\frac{\infty}{\sigma}$ & $\stackrel{\circ}{\sim}$ & $\underset{\sim}{\mathbb{N}}$ & $\begin{array}{l}\text { 苋 } \\
\text { Oे }\end{array}$ & $\begin{array}{l}\mathscr{L} \\
0 \\
0 \\
0\end{array}$ & $\begin{array}{l}\text { N } \\
\text { : }\end{array}$ & $\begin{array}{l}\overline{8} \\
0\end{array}$ & $\begin{array}{l}0 \\
\varnothing \\
0\end{array}$ \\
\hline$\frac{\vec{t}}{\frac{1}{4}}$ & 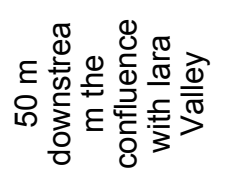 & $\stackrel{\sim}{N}$ & $\stackrel{9}{\square}$ & $\begin{array}{l}\stackrel{\nabla}{0} \\
\text { बें }\end{array}$ & $m$ & 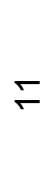 & $\begin{array}{l}\mathscr{8} \\
\stackrel{0}{0} \\
\circ\end{array}$ & ס̊ & $\begin{array}{l}\qquad 0 \\
\varnothing \\
0 \\
0\end{array}$ & 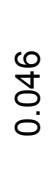 & ชิ \\
\hline
\end{tabular}

Iron, in most cases precipitates as $\mathrm{Fe}(\mathrm{OH})_{3}$ and only subordinately as carbonates. Copper generally appears as carbonate and oxide phases (Cu-C-S-O$\mathrm{H}$ system). Downstream the confluence of the creek that collects the tailings dam effluents with the clean waters of the lara Valley, a substantial drop in the salt content was noticed (sample A14).

\section{CONSIDERATIONS UPON THE POLLUTION OF THE AREA}

Pollution in the magnetite ore mining area from Băişoara-Maşca is dependent mainly on the oxidation-hydration of the sulfides, especially of pyrite, which leads to the formation of an acidic environment, enhancing the weathering phenomena, distribution and the transport of the noxious elements.

Various minerals present in the tailings can neutralize the acidic waters formed as a result of the sulfides oxidation. Carbonates and the majority of the silicate minerals, oxides and hydroxides are the most important neutralizing factors in the tailings dam. Generally the acidic waters gradually become neutral due to the weathering processes occurring at the surface of the earth's crust. Heavy metals are natural constituents of some minerals, which under normal conditions occur in low concentrations. In different parts of the ecosystem, for example as it is the case with the accumulations of mineral resources, the anthropogenic activities can result in elevated levels of these metals. Thus the heavy metals from water systems become indicators of contamination (Gaiero et al., 1997, El-Hasan et al., 2001). 
The significant amount of carbonates (dolomite and calcite) in the tailings from the Băişoara-Maşca dam plays a buffer role; the carbonates neutralize the sulfuric acid resulting from the oxidation of sulfides, therefore in the area of the mining works the $\mathrm{pH}$ is neutral, fact that makes pollution less evident in the area.

Minerals resulting from the neutralization process are dominantly sulfates of $\mathrm{M}^{2+} \mathrm{SO}_{4} \cdot \mathrm{nH}_{2} \mathrm{O}$ type. These salts are metastable and their hydrated state is dependent on the local humidity conditions. The heptahydrates precipitate under humid conditions and form efflorescences on the oxidized surfaces of the tailings dams (Jambor et al., 2000).

Pollution is caused by both the oxidation-hydration products - like goethite, and amorphous iron hydroxide - of some iron sulfides or the resulting soluble salts (mainly sulfates), and by the clay minerals (smectite, illite, illite/smectite, palygorskite) which can adsorb noxious metals and transport them to considerable distances.

According to the official Romanian soil guidelines (published in Monitorul Oficial al României, part I., no. 303 bis/6.XI.1997), the accepted level for $\mathrm{SO}_{4}{ }^{2-}$ in waters is $200 \mathrm{mg} / \mathrm{l}$ while the highest value obtained in the studied samples reaches $2320 \mathrm{mg} / \mathrm{l}$. This value is due to the high quantities of sulfates being washed/leached from the wastes contained in the tailings dam.

Comparing the metal concentrations from the studied water samples with different international guidelines (Fig. 5), it is found that they exceed the accepted levels, with the only exception of zinc. The highest excess is registered by iron.

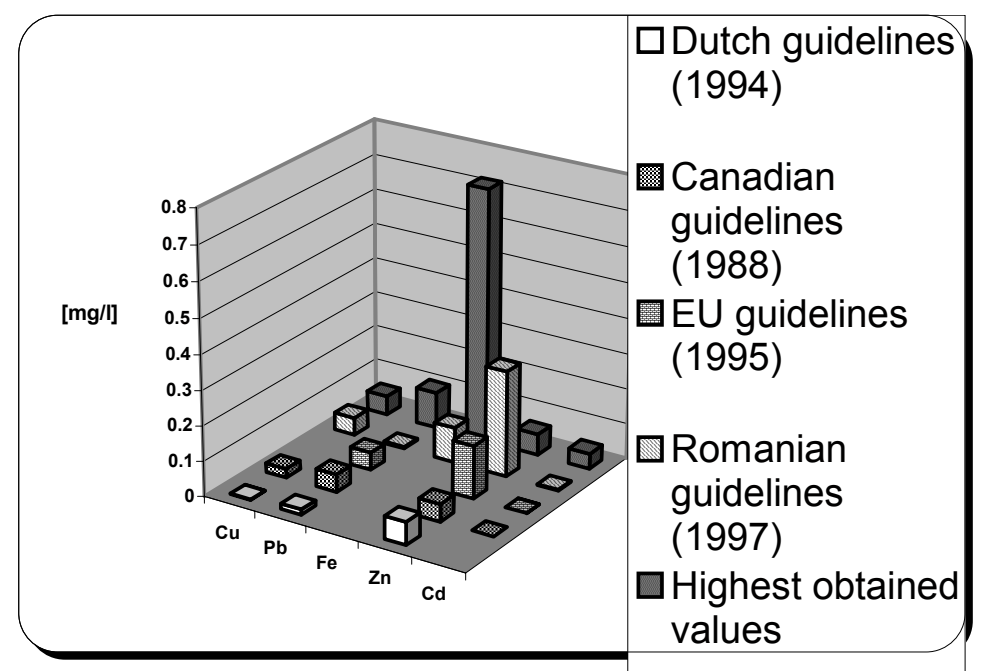

Fig. 5. Comparison of the measured heavy metal concentrations vs. different national and international guidelines.

From the presented study it can be revealed that although the acidity of the effluents originating from the tailings dam is quite low, the pollution is still present and affects both the mineralized area, and the neighboring areas. A better understanding 
of the complex geochemical phenomena occurring during the transformation processes of the minerals represents the only way for a real remediation of the polluted mining areas.

\section{CONCLUSIONS}

The magnetite mineralization from Maşca-Băişoara (the object of the mining works) is accumulated in bodies associated to garnet and/or pyroxene skarns. The tailings dam contains significant quantities of skarn minerals such as silicates (garnets, pyroxenes, amphiboles etc.), carbonates (dolomite and subordinately calcite) and metallic minerals (sulfides and oxides). All the mentioned minerals are subjects to the oxidation-hydration processes leading to the formation of various phases that play an important role in the environmental pollution (soils and waters).

The tailings dam contains minerals refractory to the exogenous factors, as well as products resulting from the reaction of carbonates and subordinately silicates with the aggressive compounds formed due to the oxidation of sulfides. In order to present the relationships between the various minerals, the following groups have been defined:

- common silicate minerals of igneous and metamorphic origin (quartz, feldspars, micas and illite);

- skarn-related minerals represented by: garnets, diopside, hedenbergite, actinolite, tremolite, epidote, zoisite, biotite, phlogopite, talc, serpentine minerals, chlorite, anatase, apatite, magnetite and hematite;

- buffer minerals (dolomite and calcite);

- polluting compounds resulted by the alteration of sulfides (pyrrhotine, pyrite, sphalerite, chalcopyrite, galena);

- neoformation minerals formed as a result of the exogenous factors; illite, illite/smectite, nontronite, palygorskite, chlorite-vermiculite, gypsum, epsomite, hexahydrite, ferrohexahydrite, bilinite(?), wattevillite, goethite, and amorphous iron hydroxide.

The majority of the minerals from the Băişoara-Maşca ore deposited earlier mentioned in literature were identified in the studied samples collected from the tailings dam, with the exception of the borates.

As a result of the weathering processes a whole series of authigenic minerals (magnesium, calcium and iron sulfates) have been formed: gypsum, epsomite, hexahydrite, wattevillite, ferrohexahydrite, hallotrichite, bilinite(?), minerals that are essential for the assessment of the level and type of pollution in the area. Some of them have never been found in this area whereas two of them are new for Romania: wattevillite, and ferrohexahydrite (Udubaşa et al., 1992; Udubaşa et al., 2002 in Szakáll, 2002).

Reaction products, mostly represented by sulfates and iron hydroxides, more abundant at the base of the tailings dam's wall in the effluence area, represent the evidence of the oxidation-hydration processes of the sulfides, especially of pyrite.

Due to the high quantities of carbonates (dolomite-calcite) present the $\mathrm{pH}$ of the environment changes from neutral to slightly alkaline. 
By fitting the Eh and $\mathrm{pH}$ values in the $\mathrm{Fe}-\mathrm{C}-\mathrm{O}-\mathrm{H}$ system, a narrow domain can be defined, overlapping the $\mathrm{Fe}(\mathrm{OH})_{3}$ and slightly the $\mathrm{Fe}^{2+}$ fields. The total dissolved salt content, calculated from the conductivity values, is high, leading to an increase of the water hardness.

The chemical analyses undertaken on water samples show high values in the soluble salts $\left(\mathrm{Na}^{+}, \mathrm{K}^{+}, \mathrm{Ca}^{2+}, \mathrm{Mg}^{2+}\right.$ and $\left.\mathrm{SO}_{4}{ }^{2-}\right)$ and heavy metals $\left(\mathrm{Cu}^{2+}, \mathrm{Pb}^{+}, \mathrm{Fe}^{2+}\right.$, $\mathrm{Fe}^{3+}$ and $\mathrm{Zn}^{2+}$ ) contents, exceeding international and national guidelines.

Although the effluents originating from the mining works area have a neutral to slightly alkaline $\mathrm{pH}$, pollution occurs and significantly impacts on both the mineralized area, and the neighboring areas.

Acknowledgements. We are grateful to Dr. Ferenc Forray for his help during sample collection. We would also like to thank Dr. Bodgan Onac for performing some of the XRD measurements.

\section{REFERENCES}

Balintoni, I. 1997 Geotectonica terenurilor metamorfice din România. Editura Carpatica, Cluj-Napoca, 100-135.

Borcoş, M., Udubaşa, G., Săndulescu, M., Krautner, H., Năstăseanu, S., Bițoianu, C., Rădan, S. (Eds.), 1984. Map of the Mineral Resources, $2^{\text {nd }}$ ed., Part one, Inst. Geol. Geophys, 236 pp., Bucureşti.

Cioflica, G., Vlad, Ş., 1973. The correlation of Laramian mettallogenetic events betonging to the Carpatho Balkan area. Rev. Roum. Géol. Géophys., Géogr., ser. Géol, 17: 217-224.

Cioflica, G., Vlad, Ş., 1984, Alpine Metallogeny in Romania. An. Inst. Geol. Geofiz., LXIV: 175-184.

El-Hasan, T., Jiries, A. 2001, Heavy metal distribution in valley sediments in Wadi Al-Karak catchment area, South Jordan. Environmental Geochemistry and Health 23: 105-116.

Gheorghițescu, D., Întorsureanu, I., Tibald, Cs., Balogh, I., 1979, On the Metallogenesis Associated to the Laramian Magmatism from the Lita - Băişoara Region (the Apuseni Mountains). Rev. Roum. Géol. Géophys., Géogr., ser. Géol, 23 (2): 167-181.

Jambor, J. L., Blowes, D. W., Ptacek, C. J. 2000, Mineralogy of mine wastes and strategies for remediation. In Environmental Mineralogy (Vanghan, D. J., Wogelius, R. A., Eds.), vol. 2, Eötvös Lóránd Univ. Press, Budapest, 255-290.

Lazăr, C., Întorsureanu, I., Popescu, M., 1972, Studiul petrografic al rocilor banatitice din zona Maşca - Băişoara (Munții Apuseni). D.S. Inst. Geol. Geofiz. LVIII (1): 143-173.

Lazăr, C., Întorsureanu, I., 1979, Contribuții la cunoaşterea zăcământului de fier de la Maşca - Băişoara (Munții Apuseni). D. S. Inst. Geol. Geofiz. LXVI: 45-69.

Rose, S., Ghazi, A. M. 1998, Experimental study of the stability of metals associated with iron oxy-hydroxides precipitated in acid mine drainage. Env. Geol. 36 (3/4): 364-370.

Szakáll, S. (Ed.) 2002, Minerals of the Carpathians. Granit, Prague, 479 pp.

Ştefan, A., Lazăr, C., Berbeleac, I., Udubaşa, G., 1988, Evolution of banatitic magmatism in the Apuseni Mts. and associated metallogenesis, D. S. Inst. Geol. Geofiz. 72-73 (2): 195-213 (1985-1986).

Udubaşa, G., Ilinca, G., Marincea, Ş., Săbău, S., Rădan, Ş. 1992, Minerals in Romania: the state of the art 1991. Romanian Journal of Mineralogy 75: 1-51. 